УДК 659.118:004

DOI: https://doi.org/10.37320/2415-3583/11.23

Журило В.В.

кандидат економічних наук, доцент, Київський національний університет імені Тараса Шевченка ORCID: https://orcid.org/0000-0002-9533-1923

\title{
МАРКЕТИНГ ВПЛИВУ ЯК КОМУНІКАЦІЙНИЙ ІНСТРУМЕНТ ПРОСУВАННЯ ТОВАРІВ У СОЦІАЛЬНИХ ІНТЕРНЕТ-МЕРЕЖАХ
}

\begin{abstract}
В статті охарактеризовано переваги залучення лідерів думок/впливових осіб у соиіальних Інтернет-мережах з метою привернення уваги цільової аудиторії, поширення рекламної інформації та встановлення інтерактивного комунікачійного зв'язку між компанією та споживачами. Охарактеризовано етапи маркетингової діяльності щодо залучення лідерів думок з метою просування товару у соиіальних Інтернет-мережах, до яких належать: визначення иілі маркетингу впливу; дослідження особливостей иільових споживачів та їх переваг при виборі впливової особи; відбір потенційних кандидатів маркетингу впливу; встановлення зв'язку з інфлюенсером та обговорення умов співпрачі; спільна розробка рекламного конщепту; реалізаџія рекламної кампанії; очінка ї̈ ефективності. За результатами вибіркового спостереження складено психографічний профіль иільової аудиторії маркетингу впливу та визначено ключові риси лідера думок, які сприяють формуванню позитивного ставлення споживачів та слідуванню запропонованих поведінкових патернів.
\end{abstract}

Ключові слова: маркетинг впливу, впливова особа, лідери думок, соціальні Інтерент-мережі, просування.

Постановка проблеми. Сьогодні сучасна компанія має у власному арсеналі безліч інструментів та технологій комунікаційного впливу на споживачів, активно запроваджує нові підходи 3 розроблення та реалізації комплексу просування продукції, залучає інноваційні канали комунікації 3 метою привернення уваги цільової аудиторії, ï інформування, переконання та формування прихильності до бренду. Більшість експертів зазначають, що традиційні рекламні засоби впливу на споживачів такі як телевізійна або навіть банерна реклама поступово втрачають свою ефективність, масові комунікації стають менш дієвими та не гарантують компанії досягнення встановлених ринкових цілей. Спостерігається опір споживача при отриманні рекламної інформації, коли він перемикає телевізійні канали, свідомо не бажаючи бути об'єктом рекламного впливу. Водночас, зростаюча активність українських користувачів в Інтернеті, популяризація соціальної взаємодії через соціальні Інтернет-мережі розширюють можливості суб'єктів підприємницької діяльності щодо залучення нових інструментів та засобів комунікаційного впливу на цільових споживачів.

Серед інноваційних технологій та новітніх інструментів маркетингових комунікацій останнім часом все більшого поширення набуває маркетинг впливу (influencer marketing), якій передбачає залучення лідерів думок або агентів впливу у соціальних Інтернет-мережах 3 метою привернення уваги цільової аудиторії та поширення рекламної інформації. Світові тенденції показують, що користувачам легше сприймати інформацію саме через соціальні мережі, оскільки такий вид спілкування не втомлює потенційних споживачів [1]. Як засіб комунікації, соціальні Інтернет- мережі створюють соціальне середовище, в якому користувачі, об'єднані спільними інтересами та цінностями, активно та всебічно взаємодіють між собою. Цей віртуальний комунікаційний простір стимулює розвиток нових, перспективних напрямків маркетингової діяльності.

Аналіз останніх досліджень i публікацій. Значний вклад у розробку теоретичних основ та визначенні особливостей практичної реалізації інноваційних інструментів маркетингових комунікацій із залученням Інтернет-мережі здійснили такі вітчизняні та зарубіжні вчені, а також експерти 3 маркетингу, як Ілляшенко С.М., Браун Д., Фіорелла С., Гунеліус С., Стелзнер М., Дорфан Дж., Сатін Д., Ньюман Д. тощо. Фахівці наголошують, що сучасні комунікації зі споживачами за допомогою Інтернет-ресурсів не тільки видозмінюють та доповнюють традиційні інструменти просування товарів та послуг, а й створюють та розвивають нові комунікаційні канали та технології. Наприклад, email-розсилка $є$ аналогом поштових розсилок, банерна реклама в Інтернеті є Інтернет-аналогом банерів на вулицях, сайт-візитівка компанії виконує роль друкованих візитівок та буклетів 3 інформацією про діяльність компанії. Розвиток Інтернет-технологій впливає на трансформацію маркетингових комунікацій в цілому, зменшуючи ефективність традиційних засобів просування та збільшуючи використання інтерактивних персоналізованих маркетингових комунікацій 3 користувачами [1]. Особливість соціальних Інтернетмереж полягає в тому, що їх сьогодні активно використовує величезна кількість користувачів, які об'єднані в соціальні групи за певними інтересами. Це можуть бути питання, пов'язані з професійною діяльністю, 3 кар'єрним зростанням, 
особистісним розвитком, реалізацією творчого потенціалу, хобі та захопленням. Створення інтерактивного зв'язку зі споживачем, швидка відповідь на його питання чи коментарі, забезпечення індивідуального підходу у його обслуговуванні та наданні інформації - ці переваги надає розвиток інтерактивного медіапростору 3 персоналізованим контентом та перетворює споживача 3 пасивного отримувача інформації на активного учасника комунікаційного процесу.

Зауважимо, що останнім часом певні дослідження з зазначеної проблематики спрямовані на визначення психологічних особливостей поведінки Інтернет-споживачів у соціальних мережах, складання психографічного профілю користувачів, визначення їх мотиваційних установок та переваг. Українські дослідники з розвитку, поширення та використання соціальних мереж зазначають, що найефективнішими інструментами та засобами привернення уваги цільової аудиторії, підтримання iї інтересу та забезпечення зворотної реакції $є$ контент-маркетинг, дизайн сторінки, швидкість реакції адміністратору сторінки на коментарі чи запити передплатників, якість та кількість відеороликів, прямі ефіри, кількість взаємодій 3 цільовою аудиторією, проведення розіграшів на сторінках тощо. Вони підкреслюють, що найбільш дієвим інструментом маркетингових комунікацій у соціальних мережах $є$ організована на постійній основі співпраця з блогерами та лідерами думок (широко застосовуються також такі назви: впливова особа, інфлюенсер). На користь застосування цього комунікаційного інструменту свідчать результати досліджень [3]:

- довіра цільової аудиторії до відгуків користувачів та спеціалістів щодо споживання товарів та брендів у соціальних мережах $є$ вищою на $65 \%$ у порівнянні з прямими каналами реклами;

- реалізація комунікаційного інструменту «лідери думок» забезпечує компанії близько $150 \%$ повернення інвестицій;

- рекомендація впливових осіб майже на $40 \%$ посилює прийняття купівельного рішення споживачем.

Мета статті полягає у визначенні етапів маркетингової діяльності щодо залучення лідерів думок 3 метою просування товару та бренду у соціальних Інтернет-мережах, а також складанні психографічного профілю цільової аудиторії маркетингу впливу та визначенні ключових рис лідера думок, які сприяють формуванню позитивного ставлення споживачів та слідуванню запропонованих поведінкових патернів.

Виклад основного матеріалу. Особливість соціальних Інтернет-мереж полягає в тому, що їх сьогодні активно використовує величезна кількість користувачів, які об'єднані в соціальні групи за певними інтересами. Це можуть бути питання, пов'язані з професійною діяльністю, з кар'єрним зростанням, особистісним розвитком, реалізацією творчого потенціалу, хобі та захопленням. Загальна сфера інтересу пов’язує між собою користувачів та лежить в основі всіх внутрішніх комунікацій. До найпопулярніших соціальних мереж у світовому та українському інтернет-просторі належать Instagram, Youtube, Facebook, Twitter та LinkedIn - ці платформи сьогодні активно використовуються для формування інтерактивного комунікаційного зв'язку з потенційними споживачами, таргетингового рекламування товарів/послуг. Так, відповідно до рейтингу топ-20 Instagramсторінок українських рітейлерів за підсумками 2019-го року перше місце належить ювелірній компанії Kochut, сторінка якої має 500 тис. фоловерів (передплатників), друге та третє місце відповідно займають мережеві рітейлери EVA и Watsons (452 тис. фоловерів у EVA та 300 тис. фоловерів у Watsons), четверте місце з кількістю передплатників 241 тис. осіб посідає Rozetka [4].

3 позиції маркетингу, агенти впливу - це люди, які своєю авторитетною думкою, судженнями та діями можуть впливати на думку інших людей, змінювати їх погляди, підштовхувати до придбання та споживання певних товарів, сприяти поширенню комерційної інформації реалізуючи власні інтереси. Специфіка просування продукту/ бренду через лідерів думок полягає в тому, що особа, яку залучають до рекламування, звертається до кола лояльних цільових споживачів, які 3 інтересом сприймають рекламну інформацію та прихильно ставляться до неї. Зазначимо, що деякі дослідники наполягають на існуванні відмінностей між впливовою особою (nfluencer) та адвокатом бренда (brand advocate). Впливова особа не $\epsilon$ споживачем бренду, якій вона рекламує, в той час як прихильник бренда є задоволеним користувачем та добровільно, за власним бажанням інформує цільову аудиторію про нього, ділиться купівельним досвідом. Головна особливість лідера думок - це здатність не тільки здійснювати комунікацію зі значною аудиторію передплатників, а також реально впливати на думки, дії, поведінку іiі представників, формувати/змінювати їх погляди, спосіб життя, ставлення до товарів та брендів. Лідер думок впливає на цільову аудиторію за допомогою емоцій та раціональних доводів, він володіє реальним авторитетом та довірою, його компетентність у певній сфері не викликає сумнівів, його поведінка $є$ прикладом для наслідування.

При цьому, на думку фахівців 3 маркетингу впливу Брауна Д. та Фіореллі С., слід класифікувати інфлюенсерів за характером зв'язку між особою впливу та його цільовою аудиторією. Експерти виокремлюють дві групи впливових осіб:

- макро-інфлюенсери - це особи, які контактують зі значною кількістю активних користувачів, 
3 якими вони мають слабко визначені або невідомі стосунки.

- мікро-інфлюенсери-це особи, які належать до соціальної групи споживача, та які мають прямий вплив на поведінку споживача, виходячи з особистісного характеру їх стосунків та комунікації [6].

Досвід співпраці з блогерами свідчить, що найефективнішою $\epsilon$ співпраця саме 3 мікроінфлюенсерами, які мають від 5 до 25 тис. передплатників [8]. Дослідження свідчать, що блогеру легше здійснювати інтерактивну комунікацію та утримувати увагу невеликої за обсягом аудиторії, відповідно, рекламування товару/бренду є більш ефективним при колаборації з мікро-інфлюенсерами. Отже, підсумуємо ключові переваги використання лідера думок як комунікаційного інструменту в маркетинговій діяльності компаній:

- привертає увагу та впливає на сприйняття цільової аудиторії;

- формує споживчу цінність продукту/бренду;

- $є$ джерелом інформації, яке характеризується високим рівнем споживацької довіри;

$-\epsilon$ ефективним комунікаційним каналом, який забезпечує зворотній зв' язок зі споживачами;
- особи, які залучаються як лідери думок, особисто зацікавлені у співпраці з метою формування власного іміджу та збільшення популярності;

- підвищує ефективність інформування цільової аудиторії про особливості споживання продукту, його унікальні характеристики, специфіку застосування;

- пряма комунікація 3 цільовою аудиторією надає можливість агентам впливу прогнозувати зміни у ринковій кон'юнктурі, передбачати ринкові тренди.

Визначимо етапи маркетингової діяльності, спрямованої на прямий або прихований вплив на цільову аудиторію за допомогою лідерів думок, послідовна реалізація яких забезпечить максимальну ефективність загальної стратегії просування компанії (рис. 1).

На першому етапі слід чітко визначити ціль маркетингової діяльності по залученню впливових осіб. Загалом, виокремлюють наступні цілі при роботі з лідерами думок:

- збільшення обізнаності аудиторії про бренд (brand awareness);

- навчання цільової аудиторії;

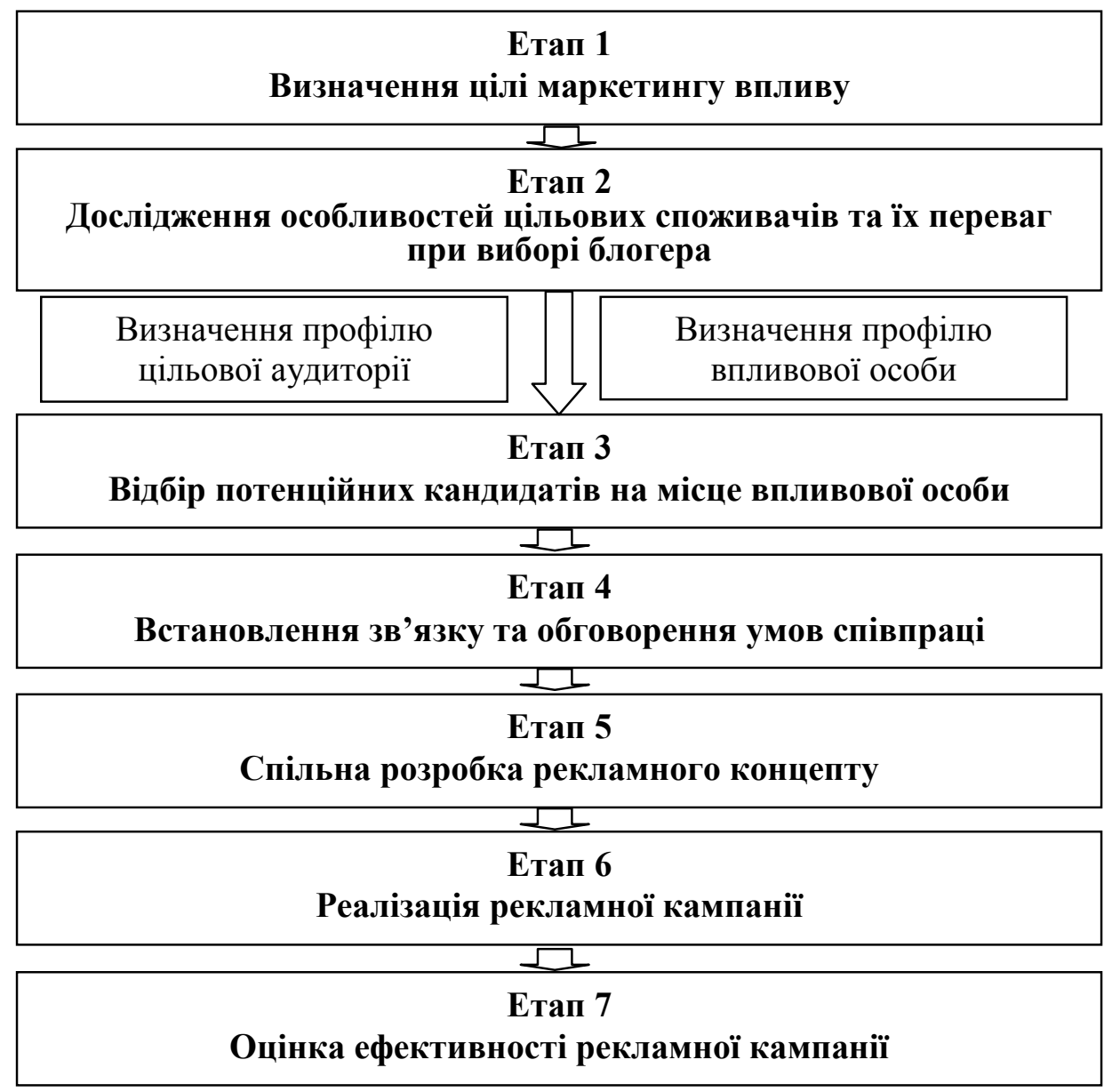

Рисунок 1 - Етапи маркетингової діяльності з залучення впливової особи для просування товару/бренду 
- збільшення трафіку сайту компанії;

- демонстрація способів/варіантів застосування продукту;

- збільшення кількості передплатників компанії у соціальних мережах;

- покращення ставлення цільової аудиторії до бренду;

- збільшення продажів,

- збільшення рівня довіри.

Другий етап - це дослідницький етап, він передбачає проведення маркетингового дослідження, мета якого полягає у складанні профілю цільової аудиторії та визначенні профілю особистості, яка має авторитет у представників цільової аудиторії та забезпечить ефективну комунікацію 3 нею. Цілеспрямованість та результативність взаємодії компанії зі споживачем грунтується на знанні його психологічного та поведінкового портрету. Оскільки складання психологічного портрету споживача та визначення характеристик людини, яка потенційно зможе впливати на нього, можливо тільки на основі первинної маркетингової інформації, тому маркетингове дослідження та проведення вибіркового спостереження $є$ обов'язковими складовими дослідницького етапу. 3 метою всебічного охоплення профілю споживачів при побудові анкети слід включити питання, які визначать їх демографічні, психологічні, економічні, соціальні та поведінкові характеристики. На нашу думку, можна виокремити певні особистісні та поведінкові ознаки, що притаманні споживачам, які позитивно ставляться до просування нових товарів/послуг відомими людьми або лідерами думок у Інтернет-мережі та які $\epsilon$ потенційною аудиторією маркетингу впливу.

Дослідники зазначають, що віковий чинники цільової аудиторії має суттєвий вплив на iii цікавість та залученість до активної комунікації 3 впливовими особами. Молодь та підлітки є особливою споживчою аудиторією в соціальних мережах, яка схильна до впливу лідерів думок, які мають певні особливості. Результати досліджень західних дослідників свідчать, що близько $70 \%$ підлітків, які $є$ активними користувачами платформи YouTube, надають перевагу «звичайним» (або «соціальним») зіркам YouTube ніж відомим широкому загалу «традиційним» зіркам. Майже 62\% респондентів віком від 13 до 24 років зазначають, що будуть активно використовувати товари та бренди, які рекомендують особи, що $\epsilon$ популярними у YouTube [2]. Молодь довіряє думці та порадам цих людей тому що вважає, що вони справжні та відверті, вміють слухати та взаємодіяти зі своїми шанувальниками, тому заслуговують на увагу та дружне ставлення.

Третій етап передбачає пошук, оцінку та вибір потенційних кандидатів на місце агентів впливу. Експерти зазначають, що 3 розвитком марке- тингу впливу та його популяризацією, компанії зіштовхнулись 3 двома ключовими проблемами це пошук осіб впливу та управління процесом взаємовідносин 3 ними. Сучасний Інтернет простір пропонує такі профільні платформи, як Тарinfluence, Upfluence, BuzzSumo, Peg, Reachbird, вони призначені для пошуку впливових осіб, огляду їхнього контенту та аудиторій, керування відноси 3 ними. Оцінювання кандидатів слід здійснювати 3 позиції досягнення максимально ефективного впливу на цільову аудиторію, тому реалізація цього етапу потребує визначення таких показників, як активність кандидатів у соціальних мережах, кількість публікацій, розмір рекламної аудиторії, яку вони мають, та потенціал їі збільшення, відсоток «лайків» і коментарів, інтенсивність публікацій, відсоток зворотної комунікації. На цьому етапі експерти рекомендують використовувати правило трьох RRR:

- relevance (актуальність). Контент впливової особи відповідає специфіці бізнесу, відповідно, його передплатникиє цільовою аудиторією впливу;

- reach (охоплення). Визначається кількість передплатників блогера, середньостатистичне охоплення його публікацій та активність фоловерів;

- resonance (резонанс). Визначається потенційний рівень залученості цільових споживачів, який інфлюенсер може забезпечити бренду.

Однак, останнім часом фахівці наголошують на тому, що існує небезпека отримати фіктивні показники, які власник сторінки штучно створює переслідуючи мету збільшення популярності власної сторінки. Наприклад, це кількість фейковий передплатників (від англійського слова fake, що означає обман, фальсифікація). Останні дослідження з цієї проблеми свідчать, що селебріті, політики та компанії часто фінансують залучення фейкових фоловерів, задля того, щоб наочно збільшити рівень власної популярності. Тому рекомендується використовувати спеціальні програмні продукти, які здатні виявити неіснуючих передплатників. Експерти передбачають, що такі параметри, як кількість реальних коментарів та відгуків, взаємодія 3 користувачами стануть найвагомішими під час вибору кандидата на місце впливової особи.

Наступний важливий момент на цьому етапі це вивчення контенту потенційного блогера, аналіз відповідності його світогляду й життєвих цінностей концепції та філософії бренда, визначення компаній та брендів, з якими блогер вже співпрацює. Якщо є така можливість, рекомендується надавати перевагу потенційному агенту впливу, якій знає бренд та має прихильність до нього. Останній фактор забезпечить стовідсоткову щирість впливової особи під час презентації продукту, рекомендації щодо його придбання та використання, зазначення споживчих переваг та власного досвіду споживання. Експерти зазна- 
чають, що цільова аудиторія відчуває щирість інфлюенсера, навіть самі блогери стають все більш перебірливими та співпрацюють не 3 кожною компанією, яка зацікавлена в ньому. Більшість 3 них відмовляється від співробітництва 3 компанією, якість продукції якої їм не подобається або імідж бренда не відповідає соціальному становищу. Існуюча колаборація блогера 3 іншими компаніями, рекламна активність на власній сторінці впливає на його імідж та формує відповідну репутацію. Експерти застережують - якщо інфлюенсер розміщує значну кількість рекламної інформації, буквально атакує передплатників замовленими постами, існує ризик втрати уваги цільової аудиторії до чергового рекламного звернення та зниження ефективності комунікаційного зв'язку. Фахівці з просування продуктів у соціальній мережі Instagram рекомендують блогерами постити 1 рекламу як мінімум на 5-10 власних різноманітних публікацій, які цікаві передплатникам.

Наступний, четвертий етап полягає у встановленні зв'язку з обраним кандидатом, отриманні згоди на співпрацю та залученню його до створення рекламного концепту. На цьому етапі вирішуються організаційні питання щодо майбутнього співробітництва. Рекомендується обрати формат співпраці та визначити термін колабораціï. Наприклад, інфлюенсер може залучатись на короткостроковий термін або стати представником бренду у довгостроковому періоді, може рекламувати бренд тільки в онлайн мережі або бути запрошеним на додаткові офлайн-заходи 3 просування. Тактичні заходи включають також рішення щодо графіку розміщення рекламного контенту, узгодження додаткових бонусів/знижок/промо-кодів, які блогер може запропонувати передплатникам, підготовку необхідних додаткових матеріалів для блогера (у разі потреби грунтовнішого вивчення ним продукту або сфери діяльності компаніiі), форми оплати (може бути запропонований бартер) та суми грошової винагороди тощо.

На п'ятому етапі відбувається спільна розробка рекламного концепту. Експерти радять не використовувати блогерами розроблені раніше шаблони рекламних текстів та зазначають, що люди цінують щирість і особистий досвід більше, ніж однотипні фото і завчені фрази [8]. Важливим на цьому кроці $\epsilon$ врахування всіх думок та рекомендацій обраної впливової особи стосовно всіх аспектів рекламної інформації та їі подання (форми, змісту, тривалості, музикального/звукового супровіду тощо). Головне завдання полягає у створенні ненав'язливого рекламного звернення або нативної реклами, що забезпечить більш ефективне залучення цільової аудиторії, підтримання iii інтересу та сприятливе ставлення. Останнім трендом є відмова від ретушування фотографій та демонстрації ідеального, «штучно створеного» життя. Експерти рекомендують давати блогерам більше свободи у виборі форми для демонстрації продукту, а також надавати перевагу відеоконтенту, в якому він ділиться особистим досвідом використання продукту, розповідає про його переваги та особливості споживання.

На шостому етапі відбувається реалізація рекламного звернення через агента впливу. Обов'язковим $є$ уникнення прямих закликів до придбання продукту компанії, який рекламується, оскільки це може привести до зворотної реакції та підштовхнути споживачів до думки, що їх використовують. Під час проведення кампанії, в разі виникнення такої необхідності, можливе корегування графіку, форми, змісту, тривалості подання рекламної інформації. Агенту впливу рекомендується активніше долучати своїх прихильників до дискусії з метою визначення ставлення до бренду, особливостей його споживання, визначення чинників, які стримують потенційних споживачів прийняти купівельне рішення або навпаки, формують їх лояльність.

На останньому, сьомому етапі здійснюється оцінка ефективності проведеної рекламної кампанії, аналізуються відгуки цільової аудиторії, іiі активність. Результати вимірювань збираються протягом усієї кампанії та включають такі якісні та кількісні показники: рекламні повідомлення, зроблені блогером, кількість «лайків» під повідомленнями, кількість переглядів публікацій та ступінь залучення до них, кількість коментарів та відповідей блогера, кількість використаних промо-кодів, кількість нових клієнтів за порадою блогера. Найважливішим показником є ROMI (Return on Marketing Investment), який розраховуються за підсумками кожної рекламної кампанії та визначається як співвідношення результату та витрат, які вкладені для його досягнення.

В аспекті досліджуваної проблематики нами було проведено вибіркове спостереження серед українських користувачів соціальних мереж. Мета опитування полягала у визначенні ставлення респондентів до рекламування товарів лідерами думок, до їхніх рекомендацій та порад щодо споживання певних продуктів, а також з'ясування загального профілю лідера думок, визначення його особистісних рис, які сприяють формуванню позитивного ставлення споживачів та слідуванню запропонованих поведінкових патернів. 3 позиції прикладного аспекту дослідження було проведено на ринку інноваційного спортивного обладнання, а саме - ринку фітнес-трекерів України. Відзначимо, що на даному етапі розвитку український ринок фітнес-трекерів знаходиться на стадії зростання та характеризується досить низьким рівнем поінформованості потенційних споживачів щодо функціональних можливостей пристрою та його 


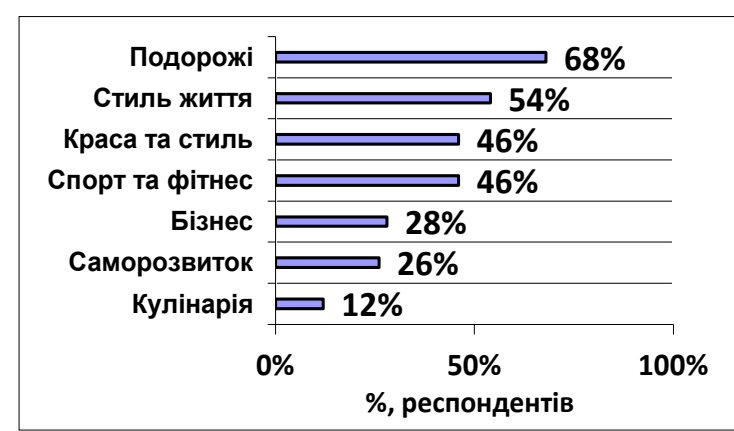

\section{Рисунок 2 - Популярні теми блогів серед респондентів}

споживчої цінності. Цільовою аудиторією проведеного дослідження виступили респонденти віком від 17 до 35 років, з середнім та вище середнього рівнем доходу, сферою діяльності: студенти, менеджери середньої ланки, фрілансери; які ведуть активний спосіб життя, мають фітнес-трекер або намір його придбати у найближчий час. Стратифікована вибірка склала - 100 осіб, опитування було здійснено за допомогою анкетування через Google-форми.

За результатами дослідження визначено ключові споживчі мотиви придбання фітнес-трекерів респондентами: 49\% респондентів використовують товар з метою контролювати свій сон, $47 \%$ респондентів мають намір слідкувати за спаленими калоріями під час заняття спортом, $45 \%$ опитаних бажають відслідковувати денну активність, аналізувати іiі та мотивувати себе до збільшення фізичної активності, 33\% респондентів зазначають зручність використання фітнес-трекера під час занять спортом замість смартфону. Підсумовуючи, можемо зазначити, що для української молоді фітнес-трекер $є$ ключовим мотиватором збільшення денної активності та засобом контролю якості відпочинку. Стосовно визначення основних каналів поширення рекламної інформації серед представників цільового сегменту було з'ясовано, що майже $90 \%$ опитаних найчастіше помічають рекламу у соціальних мережах, $48 \%$ опитаних звертають увагу на рекламу у блогерів у соціальній мережі Instagram, 34\% респондентів звертають увагу на зовнішню рекламу. Тематичні заходи виявилися на останньому місці в рейтингу, їх зазначило лише $4 \%$ респондентів. Такі засоби масмедіа, як телевізійна та радіо-реклама, а також E-mail- та SMS-розсилки не $\epsilon$ ефективними комунікаційними інструментами для цільового сегменту. Респонденти навіть відмітили, що іноді намагаються свідомо уникати контакту з рекламними повідомленнями через такі носії інформації.

За результатами дослідження найпопулярнішими соціальними мережами серед опитаних $€$ Instagram (100\% респондентів), Facebook

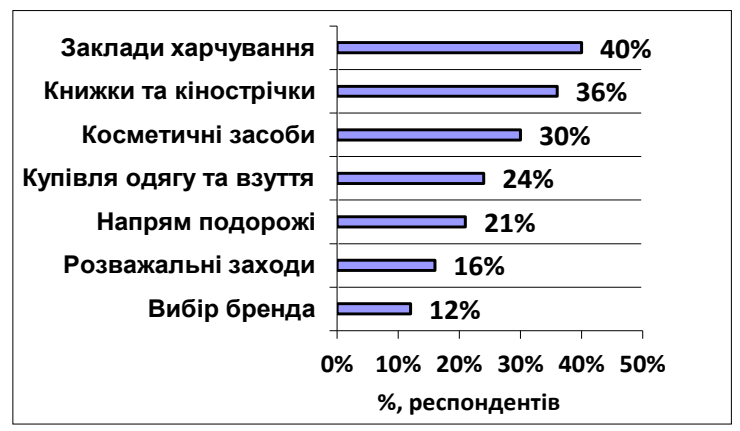

\section{Рисунок 3 - Вибір/купівля респондентами за порадою блогерів}

(82\% респондентів) та Youtube (88\% респондентів). Майже $84 \%$ опитаних зазначили, що слідкують за блогерами та лідерами думок соціальної платформи Instagram, цікавляться новими трендами, які вони презентують, здійснюють активну комунікацію ставлячи питання чи коментуючи отриману інформацію. В середньому респонденти підписані та постійно відвідують сторінки 8 блогерів, найпопулярнішими серед яких є представники музичного шоу-бізнесу, ресторанного бізнесу, «веселі блогери», які коментують події в державі та висвітлюють життєву позицію з використанням гумору, фото-блогери, лайфстайл блогери. Цільовий сегмент споживачів віддає перевагу наступним темам блогів: подорожі, лайфстайл, краса та стиль, спорт та фітнес, бізнес, саморозвиток та самопізнання, кулінарні блоги (рис. 2).

Найчастіше за порадою блогерів респонденти відвідують заклади харчування, читають книжки та переглядають кінострічки, купують косметику та засоби для догляду, купують одяг та взуття, обирають напрям для подорожей, відвідують розважальні заходи, надають перевагу певному бренду (рис. 3). На думку опитаних цікаві та успішні блогери, які мають значну кількість передплатників, відрізняються від пересічних людей, а їх успіх напряму залежить від притаманних їм індивідуальних рис. Ключовими рисами блогеру та його поведінки у соціальній мережі, на думку опитаних $\epsilon$ такі: заряджає позитивом та гарним настроєм (73\% респондентів зазначили таку рису), повинен бути відвертим та щирим (70\% респондентів), дає корисний контент та поради (68\% респондентів), підтримує зворотній зв'язок надихає та мотивує (56\% респондентів), веселий та використовує гумор (52\% респондентів).

Зауважимо, що респонденти негативно ставляться до прямих закликів впливової особи щодо придбання певного бренду. Серед опитаних $73 \%$ респондентів зазначили, що їх дратує коли улюблений блогер безпосередньо рекламує товар та закликає до його придбання. Опитані відмітили, що подібні дії з боку блогера наштовхує до думки, 
що їх використовують. Лише $14 \%$ респондентів зазначили, що повністю довіряють блогеру, a $12 \%$ опитаних обирають бренд за його порадою.

За результатами дослідження можемо виокремити певні особистісні та поведінкові ознаки, що притаманні споживачам, які позитивно ставляться до просування нових товарів/послуг відомими людьми або лідерами думок у Інтернет-мережі та які $є$ потенційною аудиторією маркетингу впливу. Ї̈̈ представники: характеризуються високим рівнем залучення у соціальне життя використовуючи соціальні Інтернет-мережі; позитивно реагують на рекламу та просування товарів та брендів у Інтеренті; вважають думки та погляди фахівців компетентними; чітко усвідомлюють особистісну та соціальну ідентичність; поділяють цінності, стиль життя, життєві погляди певної соціальної групи та діють відповідно до визначеної поведінкової моделі; є схильними до новаторства, с цікавістю й захопленням сприймають нові продукти, технології, легко змінюють стиль життя та поведінкові патерни; виявляють комунікабельність, $\epsilon$ активними у зворотному зв'язку та можуть надавати цікаві коментарі й важливі зауваження; можуть бути основними радниками у власному колі спілкування та отримують задоволення від надання рекомендацій щодо купівлі товарів.

Висновки. Високі темпи розвитку інформаційних технологій та активна комерціалізація Інтернет-простору формують підгрунтя для появи та поширення нових форматів комунікації, змінюють динаміку комунікацій та забезпечують оперативність двостороннього зв'язку між виробником й споживачем. Інноваційні інструменти просування продуктів та послуг із застосуванням агентів впливу забезпечують чітке охоплення цільової аудиторії, ефективне інтерактивне спілкування виробника 3 потенційним споживачем, формування бажаних поведінкових патернів, та загалом, сприяють реалізації економічних інтересів компанії. Слід зазначити, що ефективність лідерів думок, як комунікаційного інструмента, визначається не стільки кількістю їх передплатників, скільки здатністю залучати та підтримувати увагу власної аудиторії, стимулювати iï до взаємної комунікації, отримувати відгук.

Подальші дослідження 3 цієї проблематики доцільно спрямувати на розроблення показників ефективності рекламної діяльності із залученням впливових осіб до просування продукції у Інтернет-мережі.

\section{Список використаних джерел:}

1. Ілляшенко С.М., Іванова Т. Є. Інструменти та методи просування продукції в Internet: аналітичний огляд. Маркетинг і менеджмент інновачій. 2015, № 3. С. 20-32.

2. Mathew, J. (2018). Understanding Influencer Marketing And Why It Is So Effective. URL: www.forbes.com/ sites/theyec/2018/07/30/understanding-influencer-marketing-and-why-it-is-so-effective/\#6adf74a171a9/ (дата звернення: 25.04.2020).

3. Chen J. What is influencer marketing: How to develop your strategy. URL: https://sproutsocial.com/insights/influencermarketing/ (дата звернення: 25.04.2020).

4. Рейтинг року: топ-20 Instagram-сторінок українських рітейлерів за підсумками 2019-го. URL: https://rau.ua/novyni/ top-20-instagram-2019/ (дата звернення: 25.04.2020).

5. Як співпрацювати з блогерами в соцмережах і не знищити бренд. URL: https://raza.com.ua/iak-spivpratsiuvaty-zbloheramy-v-sotsmerezhakh-i-ne-znyshchyty-brend/ (дата звернення: 25.04.2020).

6. Brown, D. \& Fiorella, S. Influence Marketing - How to create, manage, and measure brand influencers in social media marketing. Que Publishing, 2013. 222 p.

7. The State of Influencer Marketing 2019: Benchmark Report. URL: https://influencermarketinghub.com/influencermarketing-2019-benchmark-report/ (дата звернення: 25.04.2020).

8. Смирнов К. Тренды инфлюенс-маркетинга: как рекламироваться у блогеров в 2020 году. URL: https://ppc.world/ articles/trendy-inflyuens-marketinga-kak-reklamirovatsya-u-blogerov-v-2020-godu/(дата звернення: 25.04.2020).

\section{References:}

1. Illiashenko S.M., Ivanova T.Ye. (2015). Instrumenty ta metody prosuvannia produktsii v Internet: analitychnyi ohliad [Internet promotion tools and techniques: analytical review]. Marketing and Management of Innovations, iss. 3, 20-32. (in Ukrainian).

2. Mathew, J. (2018). Understanding Influencer Marketing And Why It Is So Effective. Available at: www.forbes.com/sites/ theyec/2018/07/30/understanding-influencer-marketing-and-why-it-is-so-effective/\#6adf74a171a9/ (accessed 25 April 2020).

3. Chen J. What is influencer marketing: How to develop your strategy. Available at: https://sproutsocial.com/insights/influencer-marketing/( accessed 25 April 2020).

4. Reitynh roku: top-20 Instagram-storinok ukrainskykh riteileriv za pidsumkamy 2019. Available at: https://rau.ua/novyni/ top-20-instagram-2019/ (accessed 25 April 2020).

5. Yak spivpratsiuvaty z bloheramy v sotsmerezhakh i ne znyshchyty brend. Available at: https://raza.com.ua/iak-spivpratsiuvaty-z-bloheramy-v-sotsmerezhakh-i-ne-znyshchyty-brend/ (accessed 25 April 2020).

6. Brown, D. \& Fiorella, S. (2013). Influence Marketing - How to create, manage, and measure brand influencers in social media maketing. Que Publishing, $222 \mathrm{p}$.

7. The State of Influencer Marketing 2019: Benchmark Report. Available at: https://influencermarketinghub.com/influencer-marketing-2019-benchmark-report/( accessed 25 April 2020).

8. Smirnov K. Influence marketing trends: how to advertise throw bloggers in 2020. Available at: https://ppc.world/articles/ trendy-inflyuens-marketinga-kak-reklamirovatsya-u-blogerov-v-2020-godu/(in Russian) (accessed 25 April 2020). 
Zhurylo Victoria

Taras Shevchenko National University of Kyiv

\section{INFLUENCER MARKETING AS A COMMUNICATION TOOL FOR PROMOTING PRODUCTS IN SOCIAL NETWORKS}

For the past few years, influencer marketing is becoming more and more common in fields of innovative technologies and new tools of marketing communications. Influencer marketing constitutes involvement of opinion leaders or agents of influence on social networks aimed at attracting attention of a target audience and dissemination of advertising information. The key advantages of using this innovative marketing communications tool in the company's marketing activities are: effective informing of the target audience about the unique characteristics of the product, peculiarities of its consumption, shaping the product / brand's consumer value, forming the necessary perception of the target audience, information obtained through direct communication of the target audience with opinion leaders, enables the company to follow market trends. The article defines the stages of marketing activities oriented towards the direct or hidden influence on a target audience with the help of opinion leaders. At the first step, marketers should determine the purpose of marketing influence. At the second step, it is necessary to build a profile of a target audience, applying demographic, psychographic and behavioural features. At this step, marketers should do a consumer survey aimed at determination of a profile of a person, who has earned the confidence of representatives of a target audience and will affect them. The third step contemplates the search and assessing aspiring candidates for the position of an agent of influence. The next step consists in establishing a relation with the selected candidate, obtaining consent to collaboration. At the fifth step, marketers should involvement of the influencer in creation of an advertising concept. At the sixth step, advertising messages through a profile of an influencer are posted. The last step encompass such measures: analyzing feedbacks of a target audience and its activeness; an influencer involves followers in a discussion in order to determine their attitude to a brand, peculiarities of consumption, identification of factors impeding potential consumers to make a buying decision. According to the consumer survey, distinguish certain personal and behavioral characteristics of consumers who has positive attitude to promoting new products by opinion leaders on the Internet and who are potential audiences of influencer marketing were identified in the article.

Key words: influencer marketing, influencer, Social Networks, promotion.

JEL classification: M00, M21, M31. 